\title{
Antagonist of the Amylin Receptor Blocks $\beta$-Amyloid Toxicity in Rat Cholinergic Basal Forebrain Neurons
}

\author{
Jack H. Jhamandas and David MacTavish \\ Division of Neurology, Department of Medicine, Centre for Alzheimer and Neurodegenerative Research, University of Alberta, Edmonton, Alberta T6G 2S2, \\ Canada
}

Salvage of cholinergic neurons in the brain through a blockade of the neurotoxic effects of amyloid $\beta$ protein $(A \beta)$ is one of the major, but still elusive, therapeutic goals of current research in Alzheimer's disease (AD). To date, no receptor has been unequivocally identified for $\mathrm{A} \beta$. Human amylin, which acts via a receptor composed of the calcitonin receptor-like receptor and a receptor-associated membrane protein, possesses amyloidogenic properties and has a profile of neurotoxicity that is strikingly similar to A $\beta$. In this study, using primary cultures of rat cholinergic basal forebrain neurons, we show that acetyl-[Asn30, Tyr32] sCT(8-37) (AC187), an amylin receptor antagonist, blocks $\mathrm{A} \beta$-induced neurotoxicity. Treatment of cultures with AC187 before exposure to A $\beta$ results in significantly improved neuronal survival as judged by MTT and live-dead cell assays. Quantitative measures of A $\beta$-evoked apoptotic cell death, using Hoechst and phosphotidylserine staining, confirm neuroprotective effects of AC187. We also demonstrate that AC187 attenuates the activation of initiator and effector caspases that mediate $\mathrm{A} \beta$-induced apoptotic cell death. These data are the first to show that expression of $\mathrm{A} \beta$ toxicity may occur through the amylin receptor and suggest a novel therapeutic target for the treatment of AD.

Key words: AC187; Alzheimer's disease; diagonal band of Broca; neurodegeneration; apoptosis; caspase

\section{Introduction}

The deposition of amyloid $\beta$ protein $(\mathrm{A} \beta)$, a $39-43$ aa peptide, in the brain and the loss of cholinergic neurons in the basal forebrain nuclei are two major neuropathological and neurochemical hallmarks of Alzheimer's disease (AD), respectively (Price, 1986; Selkoe, 2002). Although A $\beta$ has been demonstrated to exert potent neurotoxic effects in a variety of experimental paradigms, there is currently no unequivocally identified receptor for such $\mathrm{A} \beta$ effects. From a therapeutic viewpoint, the search toward a target for $A \beta$ actions in the brain has assumed a new urgency, given the recent reports of adverse events in clinical trials in $A D$ patients using $\mathrm{A} \beta$ vaccine-based therapy and also concerns with secretase-based treatments (Roncarati et al., 2002; Smith et al., 2002). The existence of several putative receptor candidates for $\mathrm{A} \beta$ has been reported (e.g., receptor for advanced glycation end products, p75 neurotrophin receptor, scavenger, neuronal nicotinic, tachykinin, and serpin-enzyme complex receptors), but the functional significance of $A \beta$ interactions with such receptors in the brain has yet to be identified and remains controversial (El Khoury et al., 1996; Yan et al., 1996; Kuner et al., 1998).

Human amylin (islet amyloid peptide, diabetes-associated peptide) is a 37 aa peptide that was first isolated from amyloid

Received March 22, 2004; revised May 3, 2004; accepted May 4, 2004.

This work was supported by the Canadian Institutes of Health Research, Alberta Heritage Medical Foundation for Research, and Canada Foundation for Innovation. J.H.J. is the recipient of a Canada Research Chair in Alzheimer Research. We thank Dr. C. Hao for the use of cell culture facilities and Drs. K. Jhamandas, S. Kar, and C. Power for useful comments and suggestions on this manuscript.

Correspondence should be addressed to Dr. Jack H. Jhamandas, Division of Neurology, 530 Heritage Medical Research Centre, University of Alberta, Edmonton, Alberta T6G 2S2, Canada. E-mail: jack.jhamandas@ualberta.ca. DOI:10.1523/JNEUROSCI.1051-04.2004

Copyright @ 2004 Society for Neuroscience $\quad$ 0270-6474/04/245579-06\$15.00/0 protein deposits from the pancreatic islets of Langerhans of patients with noninsulin-dependent diabetes mellitus (Cooper et al., 1987). Despite limited primary sequence homology, human amylin shares several biophysical properties with $\mathrm{A} \beta$, including an ability to aggregate into $\beta$-pleated sheets in aqueous solutions and modulation of ion channel function (Kawahara et al., 2000; Kourie and Henry, 2002). Much of the attention on the biological significance of amylin peptides has been directed toward their anorectic, dipsogenic, and gastric-emptying effects (Young, 1997; Baldo and Kelley, 2001). However, both $\mathrm{A} \beta$ and human amylin, but not rat amylin, induce apoptotic cell death in cultured neurons and pancreatic $\beta$-islet cells (May et al., 1993). Furthermore, the profile of neurotoxicity demonstrated by human amylin is strikingly similar to that of $\mathrm{A} \beta$ in several aspects, including those related to the time- and concentration-dependent induction of apoptotic genes (Dore et al., 1997; Tucker et al., 1998). We recently identified a novel interaction of $A \beta$ and human amylin in acutely dissociated rat cholinergic basal forebrain neurons, which are selectively affected in the human condition, AD (Jhamandas et al., 2003). Using whole-cell patch-clamp recordings, we found that $\mathrm{A} \beta$ and human amylin modulate a common suite of ionic conductances and, importantly, that a specific amylin receptor antagonist, acetyl-[Asn30, Tyr32] sCT(8-37) (AC187), blocks not only the actions of human amylin but also $\mathrm{A} \beta$. An important question raised by these findings is whether $A \beta$ toxicity is dependent on the activation of a neuronal amylin receptor. The electrophysiological data have prompted us to examine the hypothesis that the neurotoxicity of $\mathrm{A} \beta$ is expressed through the amylin receptor. Using primary cultures of the rat basal forebrain neurons, our study demonstrates, for the first time, that an amylin receptor antagonist can effectively block the deleterious neu- 
rotoxic effects of $\mathrm{A} \beta$ and suggests that it may be possible to exploit its potential for therapeutic intervention in $\mathrm{AD}$.

\section{Materials and Methods}

Primary cell cultures. Primary rat basal forebrains were cultured from 16to 17-d-old embryos of time-dependent pregnant Sprague Dawley rats, as described previously (Mennicken and Quirion, 1997) and in accordance with the protocol approved by the local Health Sciences Animal Policy and Welfare Committee. Briefly, septal regions containing the basal forebrain neurons were dissected in Hanks balanced salt solution (Invitrogen, Burlington, Ontario, Canada) supplemented with $15 \mathrm{~mm}$ HEPES, $10 \mathrm{U} / \mathrm{ml}$ penicillin, and $10 \mathrm{mg} / \mathrm{ml}$ streptomycin; digested with $0.05 \%$ trypsin; triturated; and then plated on a 96 well plate $\left(5 \times 10^{5}\right.$ per well) for biochemical studies or on 12-mm-diameter coverslips (coated with $10 \mathrm{mg} / \mathrm{ml}$ poly-D-lysine) for anatomical studies. The cultures were grown at $37^{\circ} \mathrm{C}$ in a $5 \%$ humidified atmosphere in Neurobasal medium supplemented with $\mathrm{N}-2$ (Invitrogen). The medium was changed $1 \mathrm{~d}$ later, and all experiments were performed $7 \mathrm{~d}$ after cell plating. Unless specified, all reagents were obtained from Sigma (St. Louis, MO).

Treatments and cell death assays. Freshly solubilized $\mathrm{A} \beta_{1-42}, \mathrm{~A} \beta_{25-35}$, their respective inverse (biologically inactive) forms, $\mathrm{A} \beta_{42-1}$ and $\mathrm{A} \beta_{35-25}$, human amylin (SynPep, Dublin, CA), and AC187 and AC253 (kindly provided by Dr. D. Parkes, Amylin Pharmaceuticals, San Diego, CA) were prepared for application on the day of the experiment. A $\beta$ peptides were obtained from three different sources (QCB, Camarillo, CA; American Peptide, Sunnyvale, CA; and SynPep). To determine the dosedependent toxicity of $A \beta$ peptides and human amylin, cultured neurons were treated with different concentrations $(0.5-50 \mu \mathrm{M})$ of the peptides. In each experiment and in subsequent experiments described below, two rows of eight wells each (of a 96 well plate) received the same treatment, and each experiment was repeated a minimum of four times. No differences in toxicity were observed among the $\mathrm{A} \beta$ peptides from the different suppliers. To evaluate the neuroprotective effects of the amylin receptor antagonist $\mathrm{AC} 187$ against $\mathrm{A} \beta$ toxicity, cultures were exposed to $\mathrm{AC} 187$ $(10 \mu \mathrm{M})$ for $24 \mathrm{hr}$ and then $20 \mu \mathrm{M} \mathrm{A} \beta_{1-42}$ or $\mathrm{A} \beta_{25-35}$ was applied for $48 \mathrm{hr}$. To determine that the neuroprotective effects of $A C 187$ were specific for $\mathrm{A} \beta$-induced toxicity, $\mathrm{AC} 187$-pretreated cell cultures were also exposed to either staurosporine $(0.5 \mu \mathrm{M})$, a PKC inhibitor, or zinc chloride (5 $\mu \mathrm{M})$. In experiments examining time dependence of the neuroprotection by AC187, amyloid peptides were applied for up to $120 \mathrm{hr}$. Cells in adjacent rows of wells received applications of either $20 \mu \mathrm{MA} \beta_{1-42}$ or $\mathrm{A} \beta_{25-35}$ without AC187 pretreatment. Controls consisted of cells that received no drug applications or were exposed to the inverse-sequence $\mathrm{A} \beta$ peptides. In parallel experiments, AC187 was applied concomitantly with either 20 $\mu \mathrm{M} \mathrm{A} \beta_{1-42}$ or $\mathrm{A} \beta_{25-35}$. After $48 \mathrm{hr}$, the control and treated cultures were processed for (1) MTT (Sigma) and live-dead (Molecular Probes, Eugene, OR) assays to measure neuronal survival and (2) Hoechst and phosphotidylserine (PS-1; Molecular Probes) staining. Quantification of apoptotic cell death was performed using the fluorescent nuclear dye Hoechst 33342, which identifies neurons undergoing DNA fragmentation and nuclear condensation (Zhang et al., 2002). Neurons undergoing apoptotic cell death also show a translocation of PS- 1 from the cytoplasmic surface of the cell membrane to the outer leaflet of the plasma membrane. Annexin V (a phospholipid binding protein) labeled with a fluorophore can identify apoptotic cells by binding to the exposed PS-1 on the outer membrane (Koopman et al., 1994). Live-dead and Hoechststained neurons were counted on four to six coverslips $(3 \times 3 \mathrm{~mm}$ each $)$ that were plated with septal neurons, which were prepared for culture in parallel with 96 well plates for the MTT assay and treated in the same manner with $\mathrm{A} \beta$ peptides and $\mathrm{AC} 187$. Each experiment was repeated four times, and the data from coverslips after each treatment were pooled for analyses.

For experiments examining the effects of caspase inhibition on $\mathrm{A} \beta$ toxicity, the cell cultures were pretreated for $2 \mathrm{hr}$ with individual caspase inhibitors ( $20 \mu \mathrm{M}$; kit from RD Systems, Minneapolis, MN) followed by exposure to $20 \mu \mathrm{M} \mathrm{A} \beta_{1-42}$ for $48 \mathrm{hr}$. At the end of this period, the cultures were processed for MTT assay. Each experiment was performed four times.

Immunohistochemistry. Primary rat basal forebrain neurons were cul- tured on glass coverslips and immunohistochemically stained for antivesicular acetylcholine transporter (VAChT). In brief, neurons on coverslips were fixed with $4 \%$ paraformaldehyde in $0.1 \mathrm{M} \mathrm{PBS}$ and incubated overnight with the primary anti-rabbit VAChT antibody (1:500; Sigma) in PBS with $0.3 \%$ Triton X-100. Coverslips were then incubated with goat anti-rabbit IgG (1:400; Vector Laboratories, Burlingame, CA) in PBS with $0.3 \%$ Triton X-100, treated with an ABC kit (1:600; Vector Laboratories), and exposed to $0.04 \%$ DAB in PBS with $0.003 \% \mathrm{H}_{2} \mathrm{O}_{2}$. Finally, the coverslips were dried, dehydrated, and mounted on glass slides.

Immunoblotting. Western blotting was performed as described previously (Zheng et al., 2002; Y. Zhang et al., 2003). Briefly, samples of control cells and treated groups of cultured cells (treated with AC187, $\mathrm{A} \beta_{1-42}$, and $\mathrm{AC} 187$ pretreatment followed by $\mathrm{A} \beta_{1-42}$ ) with equal amounts of protein were separated by $4-20 \%$ polyacrylamide gel electrophoresis, and the resolved proteins were transferred onto nitrocellulose membranes and probed with anti-caspase 3, 8, 9, or 12 antibodies (New England Biolabs, Beverly, MA). Blots were also probed with anti- $\beta$ actin (Abcam, Cambridge, MA) as control. Each experiment for detection of caspase activation was repeated four times.

Statistical analysis. Data are presented as mean \pm SEM and were analyzed using one-way ANOVA followed by Newman-Keuls post hoc test with the level of significance set at $p<0.05$.

\section{Results}

Amylin receptor antagonism attenuates $\mathrm{A} \beta$ neurotoxicity in a concentration- and time-dependent manner

Using primary cultures of rat basal forebrain neurons (Mennicken and Quirion, 1997), where the predominant chemical phenotype is the cholinergic neuron (Fig. $1 A$ ), we established that human amylin and $\mathrm{A} \beta\left(\mathrm{A} \beta_{25-35}\right.$ and $\left.\mathrm{A} \beta_{1-42}\right)$ exert doserelated neurotoxic actions on these neurons (Fig. $1 B$ ). In keeping with previous studies (May et al., 1993; Tucker et al., 1998), neither the nonamyloidogenic rat amylin (data not shown) nor inverse-sequence $\mathrm{A} \beta$ peptides $\left(\mathrm{A} \beta_{35-25}\right.$ and $\left.\mathrm{A} \beta_{42-1}\right)$, used as controls, were neurotoxic to cultured basal forebrain neurons (Fig. $1 B)$. Pretreatment of basal forebrain neurons for $24 \mathrm{hr}$ with AC187, an amylin receptor antagonist, resulted in a significant improvement in neuronal survival as measured with two distinct methods (MTT and live-dead assays) (Figs. 1C, 2A,B). Another amylin receptor antagonist, AC253, also significantly improved neuronal survival when cells exposed to $A \beta$ were pretreated with this agent (data not shown). The AC187-induced attenuation of neurotoxicity evoked by human amylin and $\mathrm{A} \beta$ was also observable when it was coapplied with $\mathrm{A} \beta$, although not to the same degree as pretreatment with the drug (Fig. 1C). The antineurotoxic effects of $\mathrm{AC} 187$ on $\mathrm{A} \beta$ toxicity were also apparent using two other markers of apoptotic cell death (Hoechst and PS-1 staining) (Fig. 2C). Quantification of apoptotic cell death using the fluorescent nuclear dye Hoechst 33342, which identifies neurons undergoing DNA fragmentation and nuclear condensation, revealed substantive neuroprotective effects of AC187 (Fig. $2 D)$. The protective effects of AC187 were specific toward A $\beta$ mediated toxicity; staurosporine- and zinc chloride-induced apoptotic cell death were unaffected by AC187 pretreatment (Fig. $1 D)$. We subsequently determined whether the neuroprotective effects of AC187 could be sustained for longer time periods by treating the cell cultures with AC187 and then exposing them to $\mathrm{A} \beta_{1-42}(20 \mu \mathrm{M})$ for up to $120 \mathrm{hr}$. Next, the control and treated cultures were processed for markers of neuronal cell death. The results showed that AC187-treated neurons in culture continued to demonstrate significant survival in the presence of neurotoxic concentrations of $\mathrm{A} \beta$ up to this time point (Fig. $1 E$ ). 


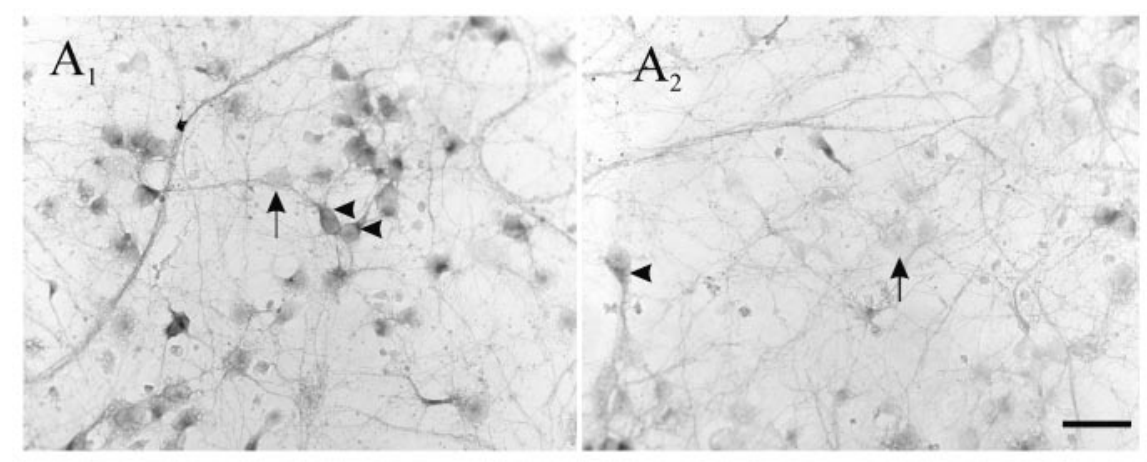

B
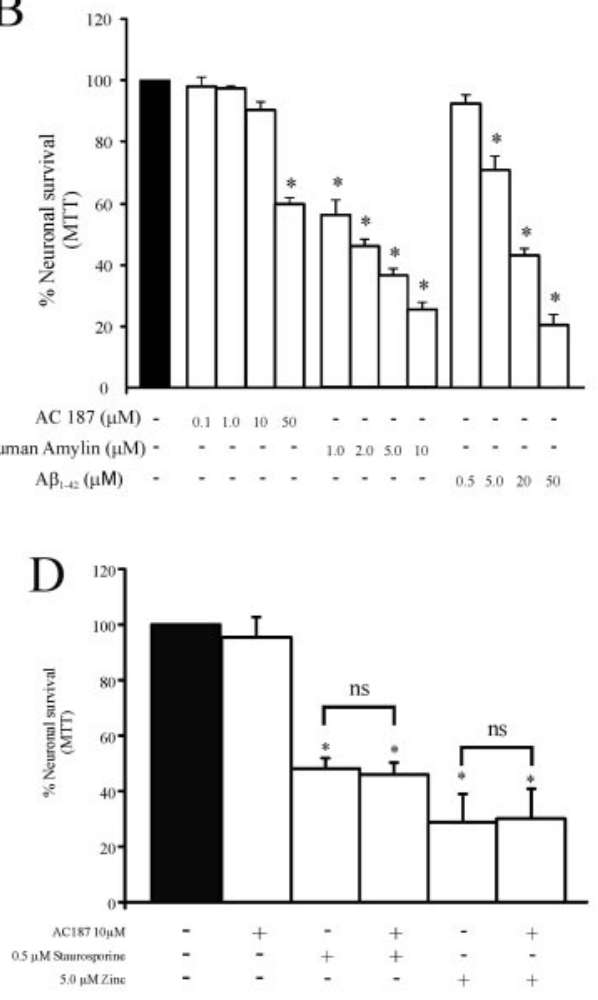

1997). In addition to activation of the executioner caspase $3, \mathrm{~A} \beta$ initiates the apoptotic cascade by activation of caspase 8,9 , or 12 pathways (Mehmet, 2000). Therefore, we determined whether antagonism of the amylin receptor is able to block the $\mathrm{A} \beta$-induced activation of caspase pathways. The basal forebrain neuronal cultures were treated with the antagonist AC187 before application of $\mathrm{A} \beta$, and antibodies to caspases $3,8,9$, and 12 were used to detect the pro-caspase substrate (and its cleaved product). Western blot analysis (Fig. 3A) showed that pretreatment with AC187 for $24 \mathrm{hr}$ effectively blocked the cleavage of caspase 3 induced by $\mathrm{A} \beta$. Application of $A \beta$ to basal forebrain neurons also results in an activation of caspases 8,9 , and 12 , which is detectable by the presence of cleaved caspase products on Western blots (Fig. 3B-E). The pretreatment of cultures with AC187 significantly attenuated or blocked the cleavage of caspases 8,9 , and 12 resulting from exposure to $A \beta$ (Fig. 3B-E). To confirm these observations, we subsequently examined the ability of a pan-caspase inhibitor, [(benzyloxycarbonyl-Val-Ala-Asp fluoromethylketone (Z-VAD-FMK)], and inhibitors of specific caspases (those that are commercially available) to block $\mathrm{A} \beta$ neurotoxicity in cultured basal forebrain neurons (Fig. $3 F)$. The pan-caspase inhibitor as well as inhibitors of caspases 3, 8, and 10 attenuated $\mathrm{A} \beta$-induced cell death as measured by the MTT assay.

\section{Discussion}

The data provide evidence that the concentration- and time-dependent in vitro neurotoxic effects of $\mathrm{A} \beta$ are expressed through the neuronal amylin receptor. Blockade of this receptor by the antagonist AC187 attenuates activation of downstream signaling pathways, mediating the A $\beta$-induced apoptotic cell death. The specificity of the neuroprotective effects of AC187 is supported by the observations that it does not affect apoptotic cell damage evoked by staurosporine and that its action is shared by another antagonist of the amylin receptor, AC253. The mechanism whereby $A \beta$ and human amylin produce a similar form of neurotoxicity is of

\section{AC187 blockade of caspase pathways activated by $\mathrm{A} \boldsymbol{\beta}$}

In most in vitro models, $A \beta$-induced neuronal cell death exhibits all of the characteristics of apoptosis (or programmed cell death), including DNA fragmentation, plasma membrane bleeding, and nuclear condensation (Yuan and Yankner, 2000). A $\beta$ may induce apoptosis by interacting with putative candidate receptors, which results in an activation of a number of cell-death signaling pathways that involve caspases. The latter constitute a family of cysteine proteases that have been identified as key regulators and effectors of the apoptotic response in several species (Villa et al., interest. One hypothesis that has been advanced is that protein misfolding results in the exposure of hydrophobic regions of proteins (such as $\mathrm{A} \beta$ and human amylin), which renders them cytotoxic. These proteins with hydrophobic domains have the ability to interact with lipid membranes, thereby inducing membrane damage and cell malfunction (Kourie and Henry, 2002). A possible mechanism for such an interaction is the ability of $A \beta$, human amylin, and prion protein to form cation-selective channels in membranes that would allow unregulated calcium entry across 
such channels (Kawahara et al., 2000). However, although $\mathrm{A} \beta$ has been shown in a variety of neuronal systems to modulate ion channel functions (Fraser et al., 1997), its ability to produce de novo ion channels has not been replicated beyond lipid bilayers (Arispe et al., 1996) or an immortalized hypothalamic cell line (Kawahara et al., 2000). An alternate possibility is that both $\mathrm{A} \beta$ and human amylin exert their toxicity through the amylin receptor, a G-proteincoupled receptor belonging to the family of calcitonin receptor-like receptors and their associated receptor-activity modifying proteins (Poyner et al., 2002). The CNS, including the basal forebrain, is enriched in amylin immunoreactivity and amylin binding sites (Van Rossum et al., 1997). Previous electrophysiological data from our laboratory have shown that $\mathrm{A} \beta$, like human amylin, inhibits a suite of potassium conductances, resulting in an increased excitability of cholinergic basal forebrain neurons, and that these effects on specific ion channels can be blocked by the amylin receptor AC187 (Jhamandas et al., 2003). Hyperexcitability of cholinergic neurons consequent to $\mathrm{A} \beta$ and human amylin could contribute to destabilization of calcium homeostasis (Mattson et al., 1993) and consequent activation of downstream calcium-dependent apoptotic pathways (Mehmet, 2000; Yuan and Yankner, 2000).

Indeed, we have demonstrated here that pretreatment with AC187 blocks the caspase activation underlying the induction of apoptosis by $\mathrm{A} \beta$ in cultured cholinergic basal forebrain neurons. Caspase 8, an initiator caspase linked to death receptor-mediated apoptosis, can on activation directly or indirectly initiate proteolytic activity of other effector caspases, including caspases 9 and 3 (Strasser et al., 2000). It would thus be expected that blocking of the upstream caspase 8 activation by the amylin antagonist would also attenuate downstream $\mathrm{A} \beta$-induced activation of caspases 3 and 9, as observed here. A similar mechanism through activation of a caspase cascade (that includes caspases 8 and 3) has been reported recently for fibrillogenic human amylin-evoked apoptosis in pancreatic $\beta$-cells (S. Zhang et al., 2003). Of the caspases shown to be activated by $\mathrm{A} \beta$, the caspase 12 pathway has evoked significant interest as a potential therapeutic target, because caspase 12 -deficient mice are resistant to $\mathrm{A} \beta$ but not other apoptotic stimuli (Nakagawa et al., 2000). The endoplasmic reticulum (ER) is a major calcium storage organelle in the cell. $\mathrm{A} \beta$ (or drugs such as thapsigargin) causes ER stress that results in depletion of ER calcium and a subsequent increase in cytosolic calcium that triggers cell death. As a part of this ER stress response, a number of ER-specific stress proteins are induced, including pro-

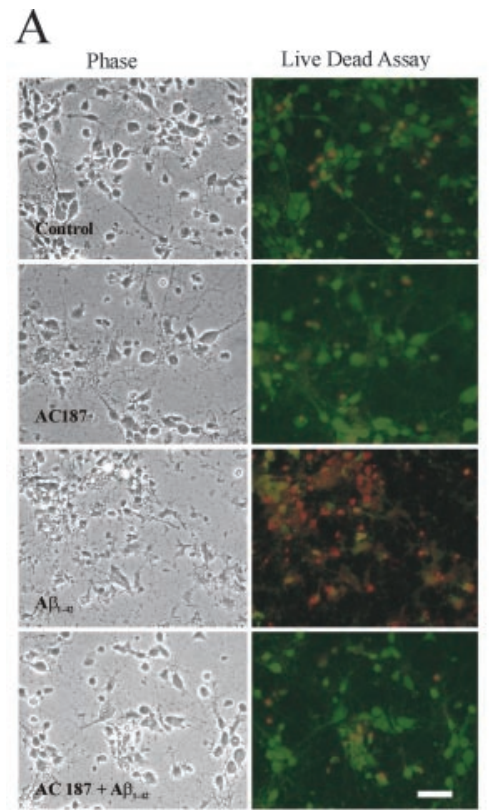

C
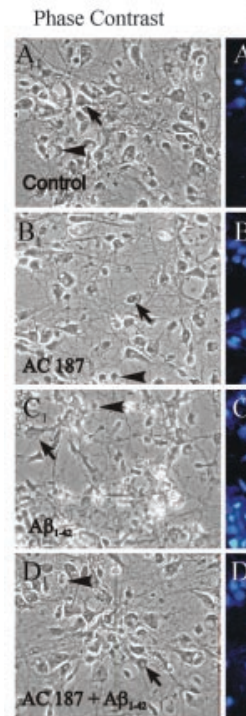

Hoechst 33342
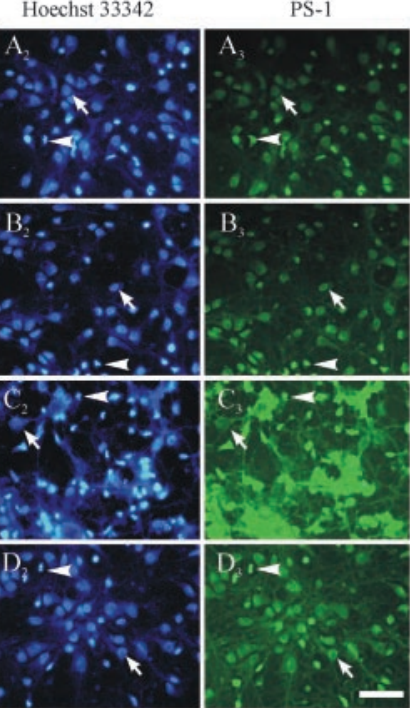

B

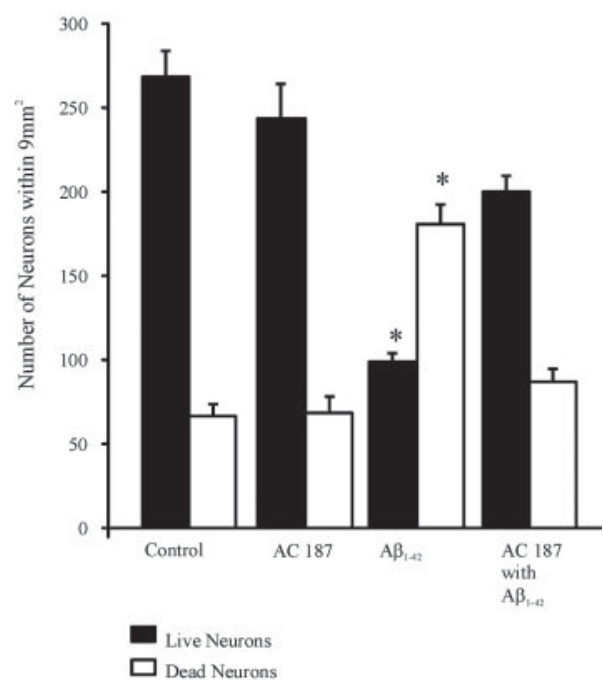

Figure 2. $\quad A \beta$ induces apoptotic cell death in cultured basal forebrain neurons that is attenuated by AC187. A, Phase-contrast and live-dead assay photomicrographs of neuronal cultures treated with AC187 without and with $A \beta_{1-42}$. For live-dead assay, live cells are green and dead cells are red. $B$, Quantification of live and dead cells with each treatment. Neurons were counted on coverslips from four independent experiments $\left({ }^{*} p<0.05\right)$. $C$, Phase-contrast microscopy $\left(A_{1}-D_{1}\right)$, Hoechst nuclear staining $\left(A_{2}-D_{2}\right)$, and PS-1 staining $\left(A_{3}-D_{3}\right)$ of basal forebrain neuronal cultures treated with AC187 and $A \beta_{1-42}$. Cells undergoing neuronal apoptosis (arrowheads) are detected by Hoechst 33342 staining $\left(A_{2}-D_{2}\right.$; nuclear fragmentation) and increased PS-1 staining $\left(A_{3}-D_{3}\right.$; green fluorophore). Arrows depict healthy neurons. $D$, Quantification of neurons with nuclear fragmentation using Hoechst staining after each treatment. Neurons were counted on coverslips from four independent experiments $\left({ }^{*} p<\right.$ 0.05). Scale bars: $A, 60 \mu \mathrm{m} ; C, 50 \mu \mathrm{m}$

caspase 12 . The pro-caspase 12 results in an activation of caspase 12 , which facilitates apoptosis through activation of the downstream executioner, caspase 3. This important $\mathrm{A} \beta$-activated pathway is also blocked by the amylin receptor antagonist AC187 in the cholinergic primary neuronal cultures. The signaling pathways that couple activation of the amylin receptor to the caspase cascade are presently unknown. However, amylin-induced activation of the c-Jun $\mathrm{NH}_{2}$-terminal kinase and p38 pathways, which have been observed in pancreatic islet $\beta$-cells (Rumora et al., 2002; S. Zhang et al., 2003), may function upstream of caspase 


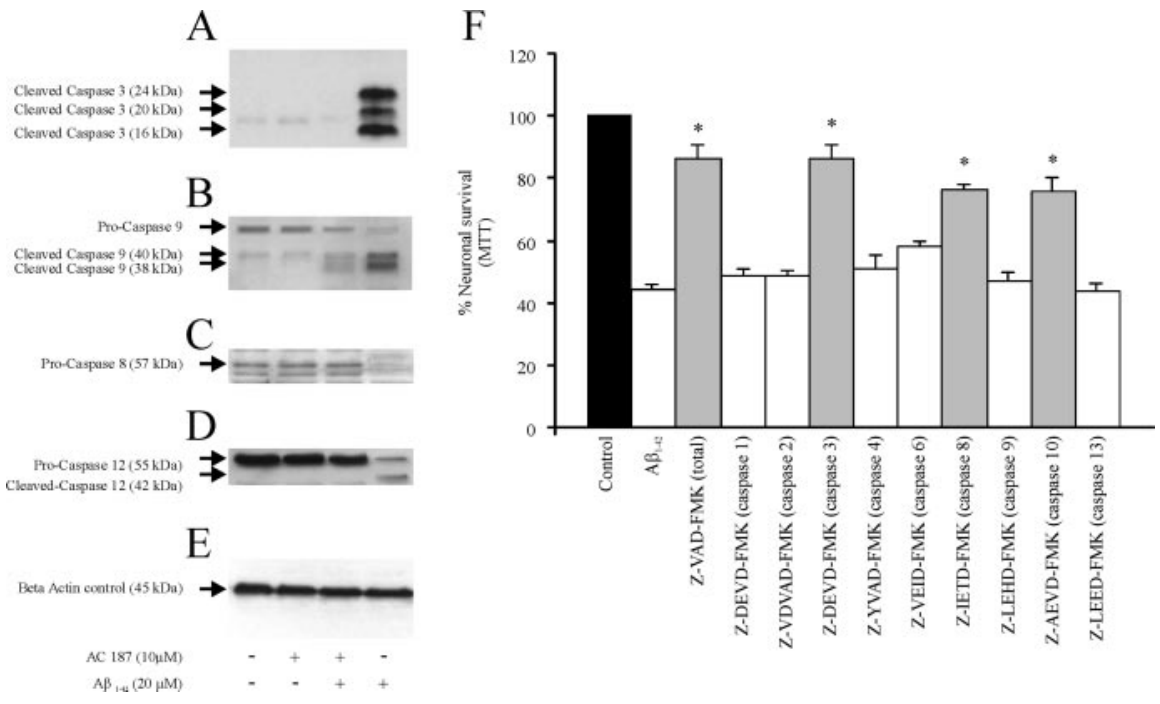

Figure 3. AC187 inhibits $A \beta$ activation of caspase pathways. $A-D$, Caspase 3 , caspase 9 , caspase 8 , and caspase 12 Western blots of lysates of cultured basal forebrain neurons exposed to $A C 187, A \beta_{1-42}$, and $A C 187$ pretreatment followed by $A \beta_{1-42}$. Pro-caspases and the presence of cleaved products signifying their activation are indicated by arrows. $E, \beta$-actin used as a loading control. Arrows point to full-length or pro-caspase and its cleaved product(s). $F$, Caspase inhibition protects against $A \beta$ neurotoxicity in cultured rat basal forebrain neurons. The pan-caspase inhibitor Z-VAD-FMK as well as inhibitors of caspases 3,8 , and 10 increase neuronal survival, as measured by MTT assay $\left({ }^{*} p<0.05\right.$ compared with $A \beta_{1-42}$ treatment; pooled data from four experiments).

activation in apoptotic signaling. These same pathways have also been shown to be activated by $\mathrm{A} \beta$ in hippocampal neurons (Wang et al., 2003) and implicated in degenerative processes in transgenic mice overexpressing the amyloid precursor protein (Otth et al., 2003).

Apart from extracellular and intracellular $\mathrm{A} \beta$, the presence of hyperphosphorylated microtubule-associated protein tau, oxidative stress, neuroinflammation, and genetic predisposition are some of the many pathogenic factors that have been implicated in cell death observed in AD (Selkoe, 2001). Similarly, multiple neurotransmitter systems are also affected in $\mathrm{AD}$, although the loss of cholinergic neurons is an early feature that has been linked to memory and cognitive dysfunction, and on which much of the current therapy in this condition is based (Kawas, 2003). Although $\mathrm{AD}$ is likely caused by mechanistically distinct pathways, attenuation of neuronal apoptosis involving several initiator and effector caspases is an important therapeutic goal. Thus, any strategy for neuroprotection of cholinergic neurons of the basal forebrain needs to produce an inhibition of multiple caspase pathways. AC187 and similar amylin receptor-based compounds that may attenuate $A \beta$ toxicity through a blockade of the amylin receptor and downstream apoptotic signaling pathways could have significant potential as a treatment approach for AD. These findings should encourage investigations to determine whether the neurotoxic effects of $A \beta$ in models overexpressing the neurotoxic peptide can be successfully modulated by treatment with amylin receptor antagonists.

\section{References}

Arispe N, Pollard HB, Rojas E (1996) $\mathrm{Zn}^{2+}$ interaction with Alzheimer amyloid $\beta$ protein calcium channels. Proc Natl Acad Sci USA 93:1710-1715.

Baldo BA, Kelley AE (2001) Amylin infusion into rat nucleus accumbens potently depresses motor activity and ingestive behavior. Am J Physiol Regul Integr Comp Physiol 281:1232-1242.

Cooper GJ, Willis AC, Clark A, Turner RC, Sim RB, Reid KB (1987) Purifi- cation and characterization of a peptide from amyloid-rich pancreases of type diabetic patients. Proc Natl Acad Sci USA 84:8628-8632.

Dore S, Kar S, Quirion R (1997) Insulin-like growth factor I protects and rescues hippocampal neurons against beta-amyloid- and human amylin-induced toxicity. Proc Natl Acad Sci USA 94:4772-4777.

El Khoury J, Hickman SE, Thomas CA, Cao L, Silverstein SC, Loike JD (1996) Scavenger receptor-mediated adhesion of microglia to $\beta$-amyloid fibrils. Nature 382:716-719.

Fraser SP, Suh YH, Djamgoz MB (1997) Ionic effects of the Alzheimer's disease $\beta$-amyloid precursor protein and its metabolic fragments. Trends Neurosci 20:67-72.

Jhamandas JH, Harris KH, Cho C, Fu W, MacTavish D (2003) Human amylin actions on rat cholinergic basal forebrain neurons: antagonism of beta-amyloid effects. J Neurophysiol 90:3130-3136.

Kawahara M, Kuroda Y, Arispe N, Rojas E (2000) Alzheimer's $\beta$-amyloid, human islet amylin and prion protein fragment evoke intracellular free calcium elevations by a common mechanism in a hypothalamic GnRH neuronal cell line. J Biol Chem 274:14077-14083.

Kawas CH (2003) Early Alzheimer's disease. N Engl J Med 349:1056-1063.

Koopman G, Reutelingsperger CP, Kuijten GA, Keehnen RM, Pals ST, van Oers MH (1994) Annexin V for flow cytometric detection of phosphatidylserine expression on cells undergoing apoptosis. Blood 84:1415-1420.

Kourie JI, Henry CL (2002) Ion channel formation and membrane-linked pathologies of misfolded hydrophobic proteins: the role of dangerous unchaperoned molecules. Clin Exp Pharmacol Physiol 29:741-753.

Kuner P, Schubenel R, Hertel C (1998) $\beta$-amyloid binds to p $75^{\text {NTR }}$ and activates $\mathrm{Nf}_{\kappa} \mathrm{B}$ in human neuroblastoma cells. J Neurosci Res 54:798-804.

Mattson MP, Barger SW, Cheng B, Lieberburg I, Smith-Swintosky VL, Rydel RE (1993) Amyloid precursor protein metabolites and loss of neuronal calcium homeostasis in Alzheimer's disease. Trends Neurosci 16:409-414.

May PC, Boggs LN, Fuson KS (1993) Neurotoxicity of human amylin in rat primary hippocampal cultures: similarity to Alzheimer's disease amyloid- $\beta$ neurotoxicity. J Neurochem 61:2330-2333.

Mehmet H (2000) Caspases find a new place to hide. Nature 403:29-30.

Mennicken F, Quirion R (1997) Interleukin-2 increases choline acetyltransferase activity in septal cell culture. Synapse 26:175-183.

Nakagawa T, Zhu T, Morishima N, Li E, Xu J, Yankner BA, Yuan J (2000) Caspase-12 mediates endoplasmic-reticulum-specific apoptosis and cytotoxicity by amyloid-beta. Nature 403:98-103.

Otth C, Mendoza-Naranjo A, Mujica L, Zambrano A, Concha II, Maccioni RB (2003) Modulation of the JNK and $\mathrm{p} 38$ pathways by cdk5 protein kinase in a transgenic mouse model of Alzheimer's disease. NeuroReport 14:2403-2409.

Poyner DR, Sexton PM, Marshall I, Smith DM, Quirion R, Born W, Muff R, Fischer JA, Foord SM (2002) International Union of Pharmacology. XXXII. The mammalian calcitonin gene-related peptides, adrenomedullin, amylin, and calcitonin receptors. Pharmacol Rev 54:233-246.

Price DL (1986) New perspectives on Alzheimer's disease. Annu Rev Neurosci 9:489-512.

Roncarati R, Sestan N, Scheinfeld MH, Berechid BE, Lopez PA, Meucci O, McGlade JC, Rakic P, D'Adamio L (2002) The gamma-secretasegenerated intracellular domain of beta-amyloid precursor protein binds Numb and inhibits Notch signaling. Proc Natl Acad Sci USA 99:102-107.

Rumora L, Hadzija M, Barisic K, Maysinger D, Grubisic TZ (2002) Amylininduced cytotoxicity is associated with activation of caspase-3 and MAP kinases. Biol Chem 383:1751-1758.

Selkoe DJ (2001) Alzheimer's disease: genes, proteins and therapy. Physiol Rev 81:741-766. 
Selkoe DJ (2002) Alzheimer's disease is a synaptic failure. Science 298:789-791.

Smith MA, Atwood CS, Joseph JA, Perry G (2002) Predicting the failure of amyloid beta vaccine. Lancet 359:1864-1865.

Strasser A, O'Connor L, Dixit VM (2000) Apoptosis signalling. Annu Rev Biochem 69:217-245.

Tucker HM, Rydel RE, Wright S, Estus S (1998) Human amylin induces "apoptotic" pattern of gene expression concomitant with cortical neuronal atrophy. J Neurochem 71:506-516.

Van Rossum D, Hanisch UK, Quirion R (1997) Neuroanatomical localization, pharmacological characterization and functions of CGRP, related peptides and their receptors. Neurosci Biobehav Rev 21:649-678.

Villa P, Kaufmann SH, Earnshaw WC (1997) Caspases and caspase inhibitors. Trends Biochem Sci 22:388-393.

Wang HY, Li W, Benedetti NJ, Lee DH (2003) Alpha 7 nicotinic acetylcholine receptors mediate beta-amyloid induced tau protein phosphorylation. J Biol Chem 278:31547-31553.

Yan SD, Chen X, Fu J, Chen M, Zhu H, Roher A, Slattery T, Zhao L, Nagashima M, Morser J, Migheli A, Nawroth P, Stern D, Schmidt AM
(1996) RAGE and amyloid-B peptide neurotoxicity in Alzheimer's disease. Nature 382:685-691.

Young A (1997) Role of amylin in nutrient intake - animal studies. Diabet Med 14 [Suppl 2]:14-18.

Yuan J, Yankner BA (2000) Apoptosis in the nervous system. Nature 407:802-809.

Zhang S, Liu J, Dragunow M, Cooper GJ (2003) Fibrillogenic amylin evokes islet beta cell apoptosis through linked activation of a caspase cascade and JNK1. J Biol Chem 278:52810-52819.

Zhang Y, McLaughlin R, Goodyer C, LeBlanc A (2002) Selective cytotoxicity of intracellular amyloid $\beta$ peptide ${ }_{1-42}$ through p53 and Bax in cultured primary human neurons. J Cell Biol 156:519-529.

Zhang Y, Hong Y, Bounhar Y, Blacker M, Roucou X, Tounekti O, Vereker E, Bowers WJ, Federoff HJ, Goodyer CG, LeBlanc A (2003) p75 neurotrophin receptor protects primary cultures of human neurons against extracellular amyloid $\beta$ peptide cytotoxicity. J Neurosci 23:7385-7394.

Zheng WH, Bastianetto S, Mennicken F, Ma W, Kar S (2002) Amyloid beta peptide induces tau phosphorylation and loss of cholinergic neurons in rat primary septal cultures. Neuroscience 115:201-211. 